\title{
MONETARY POLICY SHOCKS AND ECONOMIC GROWTH IN NIGERIA
}

https://doi.org/10.47743/jopafl-2021-22-17

\author{
Lateef Abiodun SALAMI \\ Department of Economics, Hallmark University, \\ Ijebu-Itele, Nigeria. \\ salamysalamy124@gmail.com \\ Anu K. TORIOLA \\ Department of Economic, Olabisi Onabanjo University, \\ Ago-Iwoye, Nigeria \\ toriolaanu@gmail.com
}

\begin{abstract}
This study examines monetary policy shocks and economic growth in Nigeria. This study following ex post facto research design employed a regression model where economic growth was the dependent variable while money supply, inflation and interest rate were the explanatory variables. Time series data over the period of 1986 to 2018 sourced from Central Bank of Nigeria (CBN) Statistical Bulletin and World Bank Development Index (WDI) was utilized. The study employed the Vector Autoregression (VAR) techniques in the analysis. The result of the vector autoregression estimation shows that money supply exert a significant positive effect on economic growth in Nigeria while inflation and interest rate exert an insignificant positive effect on economic growth in Nigeria. The result proves that monetary policy shocks exert a significant effect on economic growth in Nigeria while interest rate and inflation do not show any effect. It was recommended that the CBN should ensure the downward review of the Monetary Policy Rate of $12 \%$ to 9 percent so as to enhance more financial accessibility.
\end{abstract}

Keywords: Monetary policy, Economic growth, Inflation, Interest rate, Vector autoregression JEL Classification: E52, F43

\section{Introduction}

Economic growth is a key policy objective of any government because it is essential in reducing the poverty level, creation of employment opportunities and bridging the inequality gap (Anowor \& Okorie, 2016). Economic growth raised the general standard of living of the populace, makes income distribution easier to achieve, enhance time frame of accomplishing the basic needs of man to a substantial majority of the populace (Uwakaeme, 2015). When stated in terms of per capital income, economic growth is defined as aggregate output of goods and services of a country produced within a given year divided by the population (Uwakaeme, 2015). However, this output is determined by the country economic resources, the size and skill of its workforce and technological productivity of its capital stock. The growth rate of economy therefore will depend on the growth rate of these resources; physical capital and human capital as well as changes in the underlying productivity of these general inputs in the economy (Okwo, Eze \& Nwoha, 2012). Although monetary policy is one of the core drivers of economic growth and development through its impact on economic variables (Anowor \& Okorie, 2016), the role money in an economy is a subject of great controversy among contemporary Economists. 
Money on one hand affects the volume of aggregate expenditure directly through the availability of credit and on the other hand it affects the volume of aggregate expenditure indirectly through its effect on the level of interest. Besides, low interest rates leads to growth of money supply and this growth is correlated with high inflation (Okwo, Eze \& Nwoha, 2012). Accordingly, demand for money changes interest rate and changes in interest rates affect demand for investment which in turn determines income variation (Okwo, Eze \& Nwoha, 2012). Monetary policy was regarded as the major economic stabilization instrument that is used to measure, regulate, control the volume, cost, availability, and direction of money and credit within an economy in order to achieve some specified macro-economic policy objectives (Obadeyi, Okhiria \& Afolabi, 2016).

Interest rate has long been known as the most prominent transmission channel through which monetary policy affect aggregate demand in an economy. This connected with the fact that, an increase in interest rate leads to increase in the cost of capital which in turn translates to a fall in the interest rate sensitive components of aggregate demand. Equally, an increase in short-term interest rates reduces the prices of assets, which then translates to a reduction in consumption through wealth effects, and investment expenditure through Tobin's q-effects (Ridhwana, Henri, Groota, Nijkampa \& Rietvelda, 2014). Another important channel through which a tightening of monetary policy tends to depress economic activity is the credit channel. In the credit view, the contractionary effects of monetary policy are transmitted to a large extent through lower bank lending. Also, the exchange rate channel of monetary policy is crucial, especially in small open economies. The monetary tightening causes the nominal exchange rate to appreciate (Ridhwana, et al., 2014).

In Nigeria, government has always relied on monetary policy as a way of achieving certain economic objectives including employment, economic growth and development, balance of payment equilibrium and relatively stable general price level. Despite the increasing emphasis on manipulation of monetary policy in Nigeria, the problem surrounding economic growth in the county still persists. These problems include high unemployment rate, low investment, high rate of inflation and unstable foreign exchange rate all of which have affect the growth prospects and economic prosperity in the country (Nwoko, Ihemeje \& Anumadu, 2016). Against the background of sluggish and volatile rate of economic growth accompanied with declining productivity signals, and Nigeria being a developing economy characterized by significant debt burden, structural imbalance and uncertainties. Though a large body of literature linked monetary policy and growth by examining the monetary policy-growth nexus within both bivariate and multivariate frameworks, but the nexus between growth and monetary policy shocks have not been thoroughly addressed. This study intends to contribute to the existing literature by investigating the impact of monetary policy shocks on economic growth within a multivariate approach. The broad objective of this study is to examine the relationship between monetary policy shocks and economic growth in Nigeria. The research project focuses on specific objective which include:

- Examine the trend of monetary policy instruments and economic growth in Nigeria.

- Analyse the association between money supply and economic growth in Nigeria.

- Investigate the effect of monetary policy shocks on economic growth in Nigeria.

This study would be of great importance to the government in achieving the macroeconomic objectives of price stability and a well sustained economic development. 
It will equally be of ultimate importance to banks and financial institutions in carrying out the macroeconomic objectives of the country where they are operating. This research work proffer evidenced based recommendations through which the regulatory authorities can manipulate interest rates and other monetary policy tools to achieve the desired economic growth objectives. The study also adds to already existing literature on the link between monetary policy and economic growth

The study is structured into four sections. Section one as presented above is on the introduction to the subject matter. The second section focused on the review of relevant literatures while section three was devoted to the data analysis and discussion of results. The fourth section presents the conclusion and recommendations.

\section{Literature review}

Economic growth as one of the macroeconomic objective is referred as the steady course of action through which the productive and fruitful capacity of an economy is improved in due course of time to bring about increasing levels of national output and income (Todaro and Smith, 2005). According to Kuznets (1966), it is defined as a long term rise in capacity to supply increasingly diverse economic goods to its population, with the growing capacity based on advancing technology and institutional and ideological adjustments that it demands. Kindlebenger (2008) defined growth as more output derived from greater amount of input and efficiency. It is usually related to growth of potential output that is production at "full employment and economic growth is the major foundation of enhancement in level of literacy, improvement in technology and increase in the capital stock. According to Lipsey (1986), economic growth is the positive trend in the nations' total output over a long period of time. On the other end, monetary policy is policy options used deliberately by the monetary authority to control the money supply and credit condition for the purpose of achieving certain broad economic objective (Onouorah, Shaib \& Oyathelemi, 2011). It is also defined as the art of controlling the volume of money and bank credit thereby regulating cost of credit such a way it will affect aggregate demand in a direction that would bring about healthy balance of payment, price stability and job opportunity (Anyawu 1993). According to Folawewo and Osinubi (2006), monetary policy is a mixture of premeditated methods to control the cost, supply, value and of the stock of money in an economy, in line with the estimated economic activity level. Shaw (1999) defines it as "any conscious action undertaken by the monetary authorities to change the quantity, availability or cost of money. In the view of Ranlett (2005), monetary policy is the deliberate management of money supply for the explicitly purpose of attaining specific objectives or set of objectives. Monetary Policy in Nigeria is refers to the combination of measures designed to regulate the value, supply and cost of money in an economy, to match with the level of economic activities. It can also be described as the act of controlling the direction and movement of monetary policy and credit facilities in pursuance of stable price and economic growth in an economy (CBN, 1992). According to Ogunjimi (1997) three basic kinds of monetary policy decision can be made - the amount of money in circulation; the level of interest rate; and the functions of credit markets and the banking system. Abeng (2006) explained that monetary policy is valid only for a highly monetized economy. If the economy is not monetized, the efficacy of monetary policy is restricted. 
Among the core theories liking monetary policy to economic growth are the classical theory of money and Keynesian liquidity preference theory. The general classical theory of money believed that changes in the volume of money in an economy bring about changes in the price level. However, Fischer in his own submission argued that how much money is held by individual is a function of the given amount of money supply for the given time period. In the vein, the Cambridge version employed the same Fischer's money demand equation but in contrast to Fisher, submitted that money demand that is the amount of individual are will to hold is affected by wealth of people; as wealth increases then people tend to hold more money. They concluded that the demand for money is in proportion with income and $\mathrm{k}$ is the coefficient (Mishkin, 1998). In Keynes liquidity preference theory, interest rate was related with income. He affirmed that exogenous variation in money leans steadily to stimulate changes in both the velocity of money $\mathrm{V}$ and output or growth Y. Consequently, he argued that an increase in money tends to lower the interest rate by stimulating investments to grow. Also, the velocity will decrease. Keynes stated that e normal state under employment will increase the spending and the previous effects will not be temporary, so inflation will be the case (Batiz \& Batiz, 1985)

Though there several studies on the link between money and growth, limited literature abound on the implication of monetary policy shocks on growth. Among the few evidence on the monetary policy shocks and growth, Kutua and Ngalawab (2016) study how monetary policy shocks affect industrial output in BRICS countries based on Panel Structural Vector Autoregressive model. The study finds that variations in the exchange rate have the largest impact on industrial output in the BRICS countries. It is also observed that inflation rates significantly increase industrial output, peaking after about eleven months. In a similar study, Bungin (2013) assessed the impact of fiscal and monetary shock to macroeconomic variables in Serbia in period between the years 2007-2016. The structural vector autoregression results showed that both fiscal and monetary shocks affect Serbian economy. In the same direction, Adediran, Matthew, Olopade and Adegboye (2017) investigate the relationship between monetary policy shocks and inclusive growth in Nigeria based on VAR. The study found new evidence that monetary policy affect inclusive growth; inflation and macroeconomic stability in the economy. In another study, Adeoye and Saibu (2014) study the effects of monetary policy shocks using changes in various monetary policy instruments on exchange rate volatility in Nigeria. The result of the 1 ordinary least square and Engle-Granger approach to error correction mechanism model show that both real and nominal exchange rates in Nigeria have been unstable during the period under review. In the short, the variation in the monetary policy variable explains the movement/behaviour of exchange rate through a self-correcting mechanism process with little or no intervention from the monetary authority (CBN).

On the link between monetary policy and growth, Njimanted, Akume and Mukete (2016) study the impact of key monetary policy variables on the economic growth in the CEMAC zone from the period of 1981 to 2015 based on the (VAR) methodology. The study reveals that key monetary policy variables influence economic growth of the CEMAC zone in different ways with inflation rate as the impact factor. In the same vein, Sargolzaei and Ahmadi (2012) examined unexpected asymmetric effects of money on production and inflation using annual data from 1973 to 2008 in Iran. The result showed that unexpected monetary decrease has influenced on economic growth to great extent (compared with unexpected monetary increase) and unexpected monetary increase has 
largely influenced inflation (compared with unexpected monetary decrease). Similarly, Ridhwana, Henri, Groota, Nijkampa and Rietvelda (2014) study the causes of variation in the impact of monetary policies on economic development. The Vector Autoregressive (VAR) models reveal that capital intensity, financial deepening, the inflation rate, and economic size are important in explaining the variation in outcomes across regions and over time. Also, Udude (2014) examined the impact of monetary policy on the growth of Nigeria economy between the period of 1981 and 2012. The study submitted that monetary policy did not impact significantly on economic growth of Nigeria and that the inability of monetary policies to effectively maximize its policy objective most times is as a result of the shortcomings of the policy instruments used in Nigeria as such limits its contribution to growth.

\section{Data analysis and discussion of results}

This study used the quasi-experimental research design, by combining theoretical consideration (a prior criterion), and empirical observations in analyzing the effects of predictor variables on the criterion variables (Juselius, 2006). The theoretical framework for this study was anchored on the quantity theory of money first developed by Irving Fisher (Geoff, 2012). Irving Fisher, (1932) opined like other classical writers that in the short-run money control was dictated by interest rates which were sticky but in the longrun the demand for money is influence by real cash balance. He formulates his equation of exchange and specified that:

$$
\mathrm{MV}=\mathrm{PT}
$$

where $\mathrm{m}$ is the actual money stock, $\mathrm{V}$ is the transaction velocity of circulation of money, $\mathrm{p}$ is the average price level and $\mathrm{T}$ is the number of transaction made per the period. Fisher, imposes the assumption that the equilibrium values of $\mathrm{V}$, and $\mathrm{T}$ will be fairly constant in the short run and invariant with respect to change in the quality of money. Given the assumption, equation (1) can be re-written as:

$$
\mathrm{M} \bar{V}=\mathrm{P} \bar{T}
$$

where bars (-) signify that $\mathrm{v}$ and $\mathrm{t}$ are constant. Given that $\mathrm{m}$ is exogenous, there must be proportional relationship in equilibrium between money supply $(\mathrm{m})$ and the general price level (Okafor, 2009). $\mathrm{M}$ is related to $\mathrm{p}$ with a factor of proportionality $\mathrm{k}$, the relationship is given by: $\mathrm{M}=\mathrm{kPY}$

$$
\mathrm{M} / \mathrm{p}=\mathrm{KY}
$$

$\mathrm{K}$ is assumed to be constant Equation (2) can actually be written as;

$$
\mathrm{MV}=\mathrm{PY}
$$

where $\mathrm{V}=1 / \mathrm{k}$ and this is the income velocity of money, the ratio of money income (nominal GDP) to the number of times the stock of money turns over in a given period in financing the flow of nominal income. Therefore, $\mathrm{V}$ is a useful concept on policy making. Equation (3) can be written in growth form: 


$$
\mathrm{M}=\mathrm{P}+\mathrm{Y}-\mathrm{V}
$$

If $\mathrm{V}$ is constant then $\mathrm{V}-0$ so that equation (4) yields

$$
\mathrm{M}=\mathrm{P}+\mathrm{Y}
$$

This is the fulcrum of CNB monetary targeting.

In an attempt to analyze the effect of monetary policy shocks on economic growth in Nigeria, this study adapted the model used in the study conducted by Nasko (2016) on the impact of monetary policy on economic growth in Nigeria where economic growth proxy by gross domestic product was the dependent variable while money supply, interest rate and ratio of broad money supply to gross domestic product are the explanatory variables. In line with the objective of this study, economic growth proxy by gross domestic product is the dependent variable while money supply, interest rate and inflation were used as the explanatory variables in the model. The model in functional form is stated as follows:

$$
\text { RGDP }=\text { F(MS, INTR, INFL) }
$$

The transformation of the model into a VAR model is expressed in a system as:

$$
\begin{aligned}
& \text { RGDPt }=\mathrm{c} 1+\sum_{i=1}^{p} \pi 11 \text {, iRGDPt-I }+\sum_{i-1}^{p} \pi 12 \mathrm{iMSt}-\mathrm{I}+\sum_{i=1}^{p} \pi 13 \text {,iINTRt-I + } \\
& \sum_{i-1}^{p} \pi 14, \mathrm{iINFLt}-\mathrm{I}+\mu 1, \mathrm{t} . . \quad(2.10) \\
& \text { MSt }=\mathrm{c} 1+\sum_{i=1}^{p} \pi 11 \text {, } \mathrm{MSt}-\mathrm{I}+\sum_{i-1}^{p} \pi 12 \mathrm{iRGDPt}-\mathrm{i}+\sum_{i=1}^{p} \pi 13 \text {,iINTRt-i }+ \\
& \sum_{i-1}^{p} \pi 14, \mathrm{iINFLt-i}+\mu 1, \mathrm{t} \\
& \text { INTRt }=\mathrm{c} 1+\sum_{i=1}^{p} \pi 11 \text {,iINTRt-I }+\sum_{i-1}^{p} \pi 12 \mathrm{iRGDPt}-\mathrm{i}+\sum_{i=1}^{p} \pi 13 \text {,iMSt-i }+ \\
& \sum_{i-1}^{p} \pi 14, \mathrm{iINFLt}-\mathrm{i}+\mu 1, \mathrm{t} \\
& \text { INFLt }=\mathrm{c} 1+\sum_{i=1}^{p} \pi 11 \text {, iNFLt-I }+\sum_{i-1}^{p} \pi 12 \mathrm{iRGDPt}-\mathrm{i}+\sum_{i=1}^{p} \pi 13 \text {,iMSt-i }+ \\
& \sum_{i-1}^{p} \pi 14, \mathrm{iINTRt}-\mathrm{i}+\mu 1, \mathrm{t}----(2.13)
\end{aligned}
$$

The VAR (p) system equation (2) to equation (5) can be represented in a reduced form within a matrix framework as:

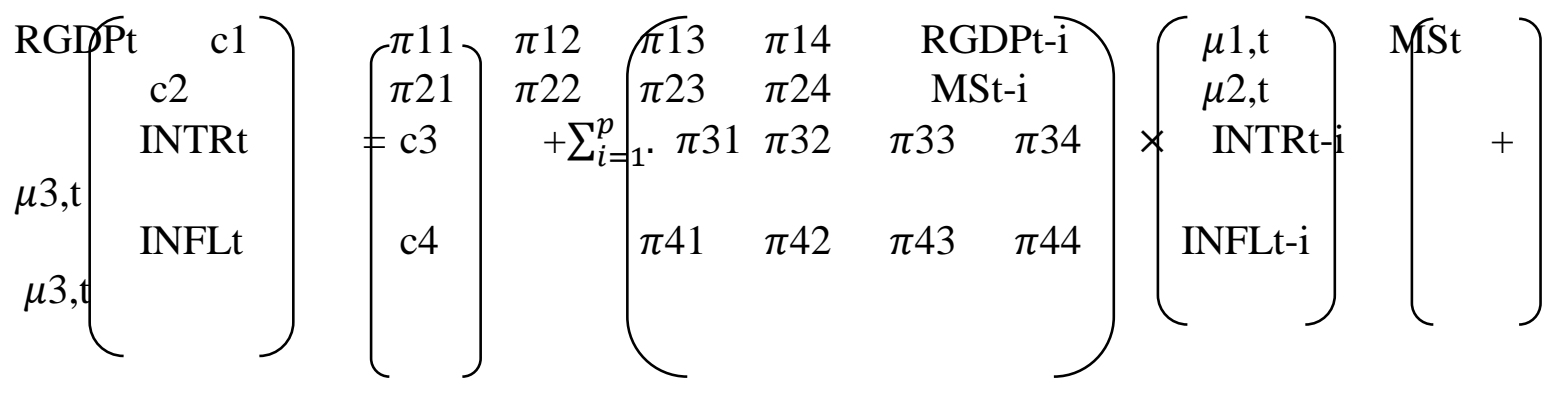

The expected signs of the coefficients of the explanatory variables are summarized in terms of differentials as follows: Money supply is expected to exert a positive effect on economic growth in Nigeria as proxy by RGDP i.e $\frac{\partial R G D P}{\partial M S}>0$; interest rate is expected to exert a negative effect on economic growth in Nigeria as proxy by RGDP i.e $\frac{\partial R G D P}{\partial I N T R}<0$, inflation 
is expected to exert a negative effect on economic growth in Nigeria as proxy by RGDP i.e $\frac{\partial R G D P}{\partial I N F L}<0$.

The data series for each of the variables which covered the periods between 1986 and 2018 for the variables in the model were obtained from the publication of central Bank of Nigeria, (CBN Annual Report), Statistical Bulletin, National Account and Bureau of Statistics. In the analsis of data, the commonly used Vector Autregressive (VAR) approach for the analysis of the effect of shocks associated with a variable on the other variable(s) was used in the analysis.

\section{Results and Discussion}

This includes descriptive statistic and correlation as follows:

Table 1: Descriptive statistics

\begin{tabular}{|c|c|c|c|c|}
\hline & RGDP & MS & INTR & INFL \\
\hline Mean & 34530.04 & 4842.205 & 12.70323 & 18.10000 \\
\hline Median & 25267.54 & 1269.320 & 11.88000 & 12.70000 \\
\hline Maximum & 69023.93 & 21607.68 & 28.02000 & 57.20000 \\
\hline Minimum & 15237.99 & 23.81000 & 6.300000 & -14.10000 \\
\hline Std. Dev. & 18086.69 & 6626.223 & 5.276541 & 17.65514 \\
\hline Skewness & 0.708861 & 1.235272 & 1.134955 & 1.076240 \\
\hline Kurtosis & 2.026670 & 3.133355 & 3.789054 & 3.424282 \\
\hline Jarque-Bera & 3.819854 & 7.906774 & 7.459496 & 0.217035 \\
\hline Probability & 0.148091 & 0.019190 & 0.023999 & 561.1000 \\
\hline Sum & 1070431. & 150108.4 & 393.8000 & 9351.120 \\
\hline Sum Sq. Dev. & $9.81 \mathrm{E}+09$ & $1.32 \mathrm{E}+09$ & 835.2567 & 31 \\
\hline Observations & 31 & 31 & 31 & \\
\hline
\end{tabular}

Source: Author, 2019

In Table 1, the mean of economic growth, money supply, interest rate and inflation greater than their medians implying that the variables are positively skewed. The skewness coefficient of money supply, interest rate and inflation are greater than one indicating that these variables are highly symmetrical except for economic growth. The Jarque-Bera statistics shows that except for economic growth all other variables in data set are normally distributed since their p-values are statistically significant at 5\% level of significant.

Table 2: Correlation analysis matrix

\begin{tabular}{|c|c|c|c|c|}
\hline & RGDP & MS & INTR & INFL \\
\hline RGDP & 1 & & & \\
\hline MS & 0.666200 & 1 & & \\
\hline INTR & -0.609105 & -0.536915 & & 1 \\
\hline INFL & -0.333267 & -0.268072 & 0.551465 & 1 \\
\hline
\end{tabular}

Source: Author, 2019 
In Table 2 there was statistical evidence that money supply have a positive association with economic growth while interest rate and inflation have a negative association with economic growth in Nigeria. The result also showed that the association among the variables is not very strong indicating the absence of the problem of multicorrelation among the independent variables. The trend of monetary policy variables and economic growth in Nigeria is presented using the line graph as follows

Figure 1: Trend of economic growth in Nigeria 1986-2018

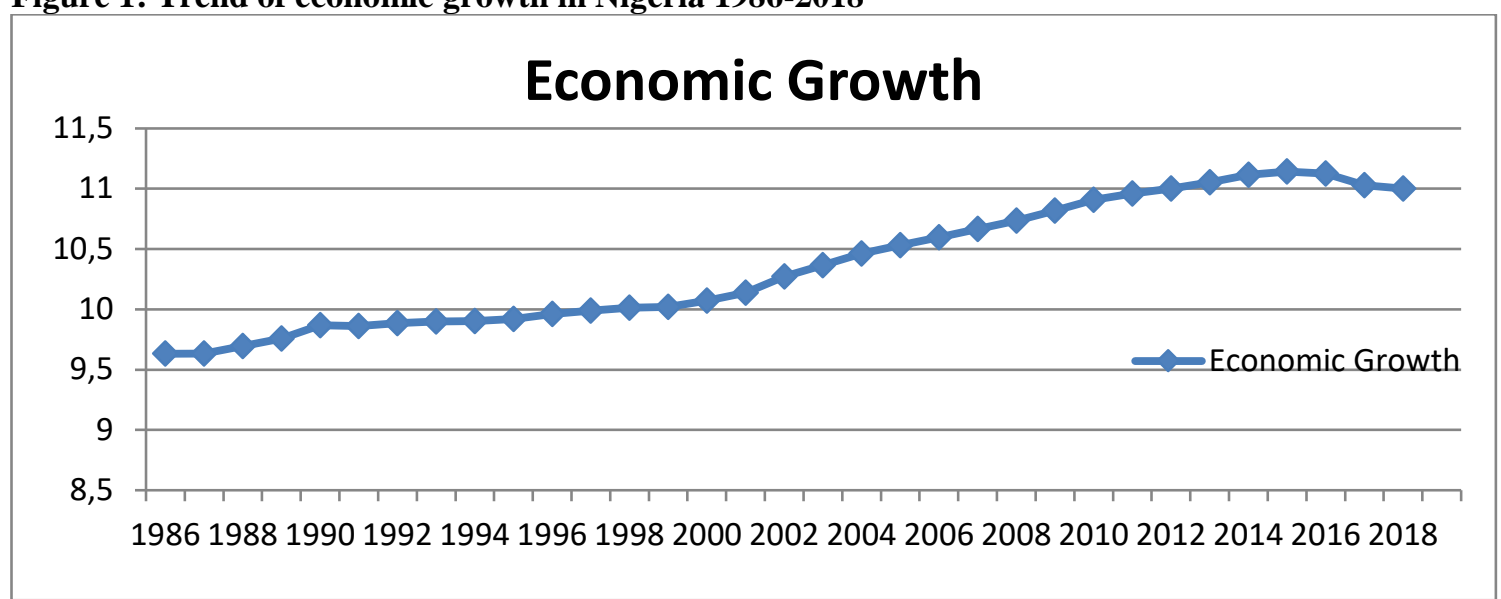

Source: Author, 2019

Figure 1 showed that over the entire period, economic growth has been growing sluggishly in Nigeria. In addition, for some years, there was an increase in the pace of economic growth and for other years the trend of economic growth falls. The rise and fall in economic growth in Nigeria for some years can be attributed to the rise and fall in international oil price since the economy is dependent on oil revenue.

Figure 2: Trend of money supply in Nigeria 1986-2018

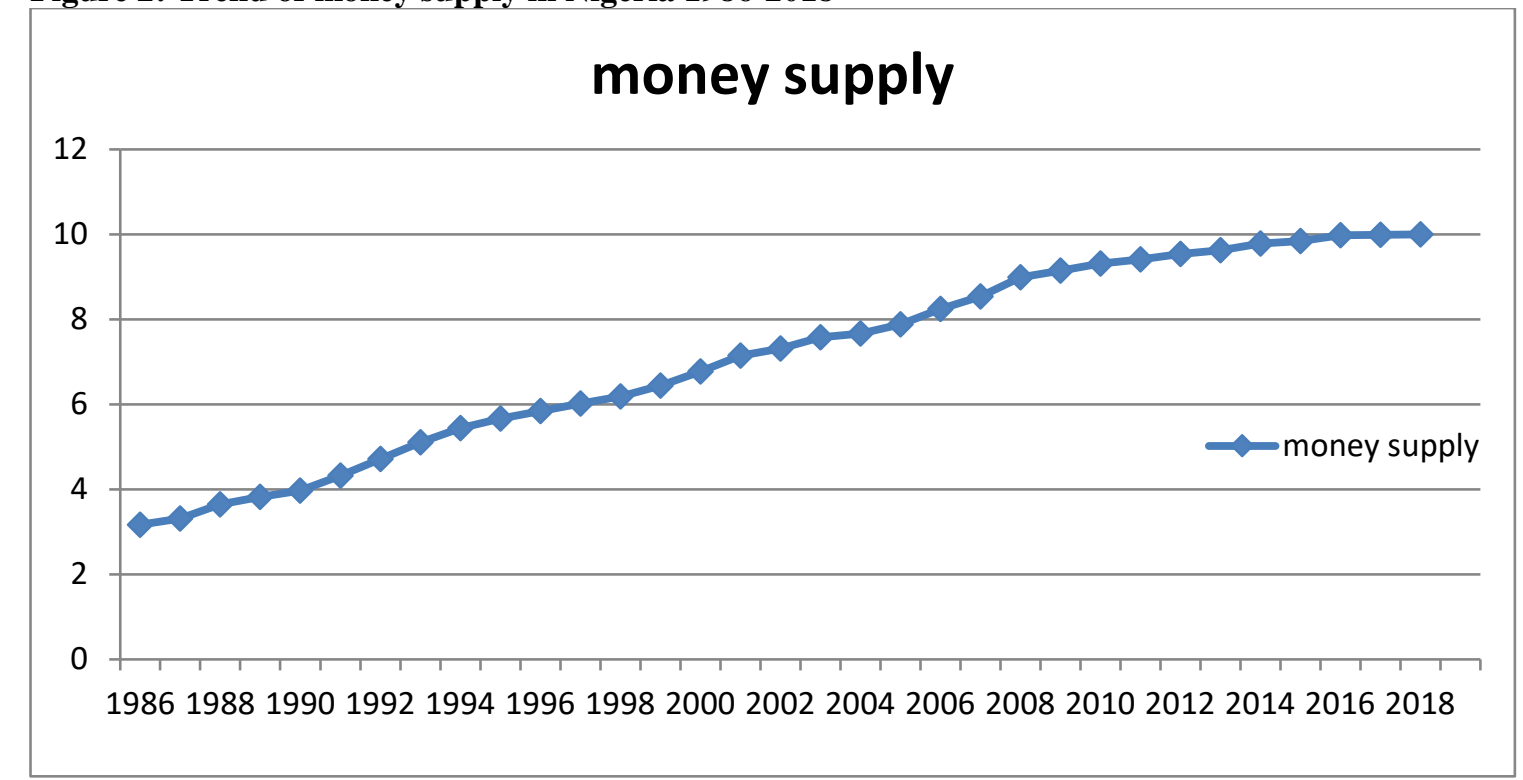

Source: Author, 2019 
Figure 2 showed that over the entire period, money supply has been growing rapidly in Nigeria. The continuous increase in money supply suggest that the monetary authority has being doing all within her capacity to ensure a sound financial system through the supply of money and regulatory policy.

The model is estimated using VAR estimates. In VAR methodology, much interest is not on the coefficients of VAR, because it does not make much meaning in economics; rather the focus is on the variance decomposition and the impulse functions. The coefficient of VAR estimates and variance decomposition is presented in table 4 while the variance decomposition is reported in table 5 as follows:

Table 4: Result of VAR estimates

\begin{tabular}{|c|c|c|c|c|}
\hline Dependent Variables & M2 t-1 & INFL t-1 & EXCR t-1 & INTR t-1 \\
\hline LOG(RGDP(-1)) & 0.899452 & -0.158316 & 6.388833 & 23.74957 \\
\hline & $(0.04283)$ & $(0.13942)$ & $(4.95420)$ & $(22.3305)$ \\
\hline & {$[17.0250]$} & {$[1.13557]$} & {$[1.28958]$} & {$[1.06355]$} \\
\hline LOG(MS(-1)) & 0.025985 & 1.026659 & -2.713553 & -6.849340 \\
\hline & $(0.01263)$ & $(0.03333)$ & $(1.18448)$ & $(5.33891)$ \\
\hline & {$[2.05722]$} & {$[30.8008]$} & {$[-2.29093]$} & {$[-1.28291]$} \\
\hline & -0.000579 & 0.011526 & 0.242748 & 0.971990 \\
\hline INTR(-1) & $(0.00184)$ & $(0.00485)$ & $(0.17237)$ & $(0.77694)$ \\
\hline & {$[-0.31516]$} & {$[2.37621]$} & {$[1.40830]$} & {$[1.25106]$} \\
\hline & 0.000309 & -0.002424 & 0.043696 & 0.210257 \\
\hline INFL(-1) & $(0.00044)$ & $(0.00116)$ & $(0.04134)$ & $(0.18634)$ \\
\hline & {$[0.70100]$} & {$[-2.08360]$} & {$[1.05696]$} & {$[1.12834]$} \\
\hline C & & & -38.39959 & -195.6112 \\
\hline C & 0.909759 & 1.571642 & $(43.3528)$ & $(195.408)$ \\
\hline R-squared & $(0.46231)$ & $(1.21998)$ & {$[-0.88575]$} & {$[-1.00104]$} \\
\hline Adj. R-squared & {$[1.96784]$} & {$[1.28825]$} & & \\
\hline Log likelihood & 0.994553 & & & \\
\hline Akaike AIC & 0.060025 & & & \\
\hline
\end{tabular}

Standard errors in ( ) \& t-statistics in [ ]

Source: Author, 2019

The VAR estimates presented in Table 4 showed that there is statistical evidence that changes in economic growth is influence positively by changes in money supply ( $\beta=$ -12.34828, $\mathrm{t}=-2.33651, \mathrm{p}<.05)$ and its own shocks $(\beta=0.04283, \mathrm{t}=17.0250, \mathrm{p}<.05)$ while changes in inflation and interest rate do not influence changes in economic growth in Nigeria. The implication of this result is that, it is only changes in money supply that influence changes in economic growth in Nigeria.

The impulse response function was used to investigate how economic growth respond to shocks in monetary policy. The results of the impulse response between economic growth and monetary policy variables are presented in figure 3 below: 
Figure 3: Impulse Response Function: Monetary Policy Variables and Economic Growth
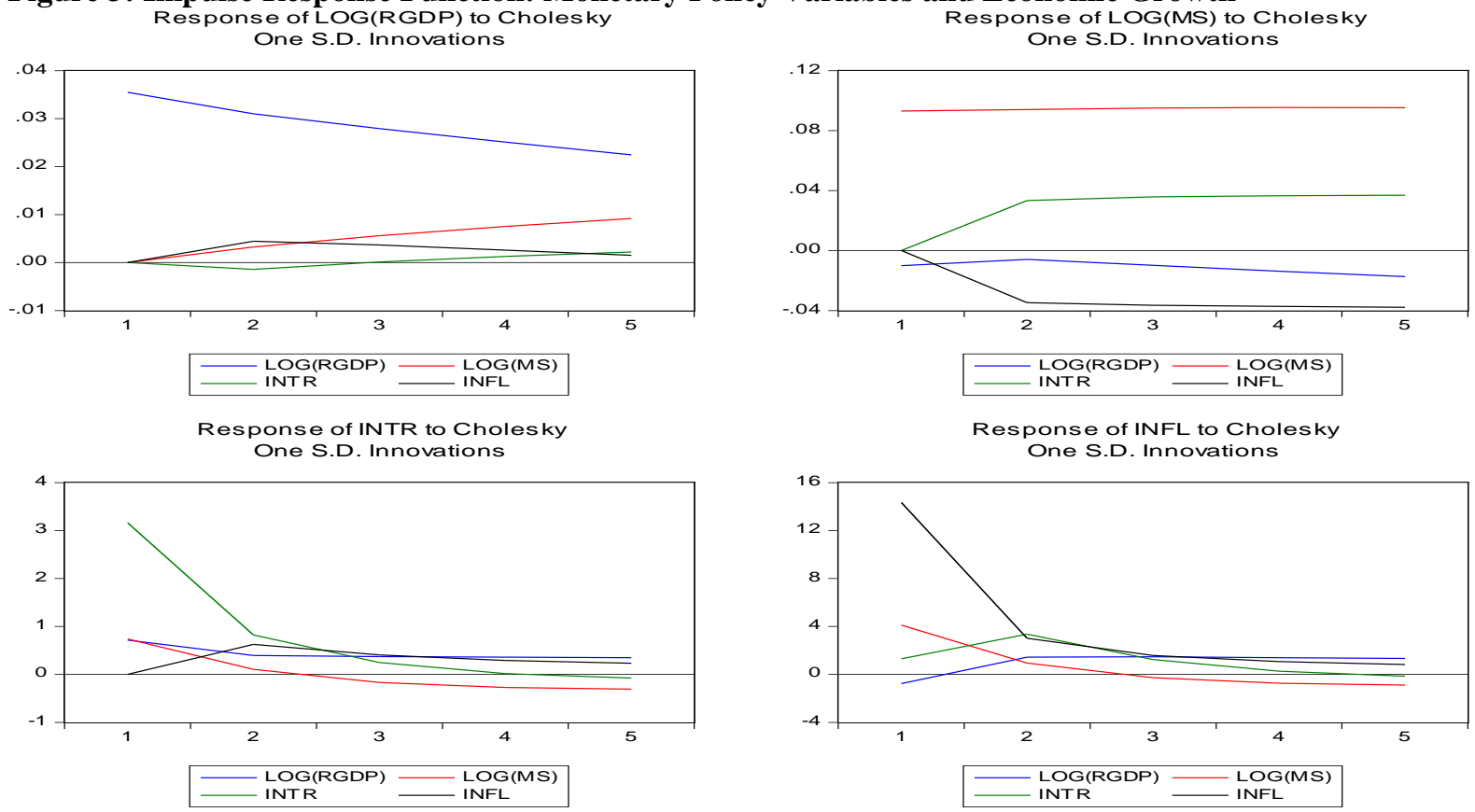

Source: Author, 2019

Shocks in money supply lead to a long term decrease in economic growth as shown in the figure 3 above. The improvements in money supply resulted in a sharp decrease in economic growth in the second year to the third year, but later remains under the steady state with a new equilibrium state implying permanent effect from the third to the fourth year after which there was a sharp increase in stock market capitalisation in the fifth year. Shock money supply also leads to a rise in inflation and a decline in interest rate below the steady state.

The variance decomposition in VAR separates the variation in an endogenous variable into component. Thus, variance provides information about the relative importance of each random innovation in affecting the variables in the VAR. The reduced form of the VAR obtained using Sims's recursive Choleski decomposition method is reported as follows:

Table 4: Results of Variance Decomposition of Economic growth from VAR

Response of LOG(RGDP):

\begin{tabular}{|c|c|c|c|c|}
\hline Period & LOG(RGDP) & LOG(MS) & INTR & INFL \\
\hline 1 & 0.035461 & 0.000000 & 0.000000 & 0.000000 \\
\hline & $(0.00458)$ & $(0.00000)$ & $(0.00000)$ & $0.00000)$ \\
\hline 2 & 0.030981 & 0.003259 & -0.001430 & $(0.00635)$ \\
\hline 3 & $(0.00477)$ & $(0.00254)$ & $(0.00566)$ & 0.003651 \\
\hline & 0.027932 & 0.005605 & 0.000136 & $(0.00654)$ \\
\hline 4 & $(0.00531)$ & $(0.00331)$ & $(0.00632)$ & 0.002591 \\
\hline
\end{tabular}




\begin{tabular}{|c|c|c|c|c|}
\hline & $(0.00607)$ & $(0.00367)$ & $(0.00628)$ & $(0.00647)$ \\
\hline 5 & 0.022444 & 0.009176 & 0.002184 & 0.001525 \\
\hline & $(0.00685)$ & $(0.00391)$ & $(0.00596)$ & $(0.00631)$ \\
\hline
\end{tabular}

Source: Author, 2019

The result of the impulse response in figure 3 and variance decomposition in Table 4 reveals that at 5 horizon, $0.07 \%$ of the variance in economic growth is explained by its own shocks while money supply contributed $0.03 \%$, interest rate contributed $0.06 \%$ and inflation rate $0.06 \%$. The result comes into alignment with theoretical study that causation monetary policy and economic growth in Nigeria is significant, and as such, changes in money supply predicted changes in inflation.

\section{Discussion of results}

The result of the vector autoregression estimation shows that money supply exert a significant positive effect on economic growth in Nigeria while inflation and interest rate exert an insignificant positive effect on economic growth in Nigeria at 5\% level of significance. The implication of this result is that, it is only changes in money supply that influence changes in economic growth in Nigeria. By and large our result established that monetary policy shocks exert a significant effect on economic growth in Nigeria. This result corroborated the findings of Ismail, Adegbemi and Mariam (2013) on the impact of monetary policy on economic growth in Nigeria where a long run relationship was established among the variables and inflation rate, exchange rate and external reserve were found to be monetary policy instruments that significantly drive growth in Nigeria. It also gave credence to the findings of Adeoye and Saibu (2014) on the effects of monetary policy shocks using changes in various monetary policy instruments on exchange rate volatility in Nigeria where it was found that variation in the monetary policy variable explains the movement/behaviour of exchange rate through a self-correcting mechanism process with little or no intervention from the monetary authority (CBN). However, the result was in contrast to the findings of Udude (2014) on the impact of monetary policy on the growth of Nigeria which established that only exchange rate exerted significant impact on economic growth in Nigeria while other variables did not.

\section{Conclusion and recommendations}

This study concluded that monetary policy shocks exert a significant effect on economic growth in Nigeria while interest rate and inflation do not show any effect on economic growth in Nigeria. The implication of this result is that, it is only changes in money supply that influence changes in economic growth in Nigeria. This result is attributed to the ability of the Nigerian government to effectively regulate some other important macroeconomic variables which can infuriate interest rate which has thereby helped curtail the effects of interest rate and inflation during the study period. This is an indication that monetary authorities might have initiated policies that helped absorb the influence of macroeconomic instability on economic growth in Nigeria. 
Following the empirical findings, the following recommendations are made for effective policy formulations: that the Central Bank of Nigeria should promote financial inclusion and accessibility of finance to the economically active poor and the micro entrepreneurs. Also the CBN should ensure the downward review of the monetary policy rate of $12 \%$ to 9 percent so as to enhance more financial accessibility and inclusion with a low interest rate, thereby encouraging borrowing for potential entrepreneurs and the economically active poor. Equally, government through collaborative effort with the organized private sector must work to ensure stable price level through the use of monetary policy.

\section{References}

1. Adediran, O.S, Matthew, O.A, Olopade, B.C. \& Adegboye, F.B. (2017). Monetary policy shocks and inclusive growth in Nigeria: A VAR approach, The International Journal of Humanities \& Social Studies, 5(2), 1-14 http://eprints.covenantuniversity.edu.ng/id/eprint/8361

2. Adeoye, B.W \& Saibu,O.M (2014). Monetary policy shocks and exchange rate volatility in Nigeria, Asian Economic and Financial Review, 4(4):544-562 544

3. Akanni K.A \& Osinowo O.H. (2013). Effect of fiscal instability on economic growth in Nigeria, Advances In Economics And Business 1(2): 124-133 https://doi.org/10.13189/aeb.2013.010207

4. Alley, I, Ayodele, A Mobolaji, H \& Adeniran, Y. A (2014). Oil price shocks and nigerian economic growth, European Scientific Journal, 10(19), 11-21

5. Anowor, O.F. \& Okorie, G.C (2016). A reassessment of the impact of monetary policy on economic growth: Study of Nigeria, International Journal of Developing and Emerging Economies, 4(1), 82-90 http://eprints.gouni.edu.ng/id/eprint/1235

6. Apere, T.O. (2017). Impact of crude oil on Nigeria’s fiscal policy formulation, European Journal of Research in Social Sciences, 5(3), 11-21.

7. Apere, T.O \& Karimo, T.M. (2014). Monetary policy effectiveness, output growth and inflation in Nigeria, International Journal of Economics, Finance and Management, 3(6), 12-17.

8. $\quad$ Asandului, M., Lupu, D., Maha, L. G., \& Viorică, D. (2021). The asymmetric effects of fiscal policy on inflation and economic activity in post-communist European countries. Post-Communist Economies. 899919 https://doi.org/10.1080/14631377.2020.1867430

9. Bungin, S. (2013). The impact of fiscal and monetary shock on economic activity in Serbia: SVAR Approach , Original Scientific Paper

10. Chuku A.C. (2009). Measuring The effects of monetary policy innovations in Nigeria: A Structural Vector Autoregressive (SVAR) approach, African Journal of Accounting, Economics, Finance and Banking Research, 5(5), 2-15.

11. Gokal, V \& Hanif, S (2004). Relationship between inflation and economic growth, Working Paper,

04

12. Ismail O. F, Adegbemi B.O. \& Mariam, A.A (2013). Does monetary policy influence economic growth in Nigeria?, Asian Economic and Financial Review , 3(5):635-646 http://aessweb.com/journaldetail.php?id=5002

13. Komijani, A, Sargolzaei, M, Ahmad, R, \& Ahmadi, M. (2012). Asymmetric effects of monetary shocks on economic growth \& inflation: Case study in Iran, International Journal of Business And Social Science, 3(9), 224

14. Kutua, A.A \& Ngalawab, H (2016). Monetary policy shocks and industrial output in BRICS countries, Spoudai Journal of Economics and Business, 66(3), 3-24

15. Lupu, D. (2019). Financial development and economic growth in Eastern Europe. Journal of Public Administration, Finance and Law, (16), 157-165.

16. Mbutor, M.O. \& Uba, I.A (2013). The impact of financial inclusion on monetary policy in Nigeria, Journal of Economics and International Finance, 5(8), 318-326 https://doi.org/10.5897/JEIF2013.0541 
17. Nasko,A.M (2016). Impact of monetary policy on the economy of Nigeria, Pyrex Journal of Business and Finance Management Research, 2 (10), 163-179

18. Njimanted,F.G, Akume, D \& Mukete, E.M (2016). The impact of key monetary variables on the economic growth of the Cemac Zone, Expert Journal of Economics, 4(2), 54-67

19. Nwoko, N.M., Ihemeje, J.C. \& Anumadu, E. (2016). The impact of monetary policy on the economic growth of Nigeria, An International Multi-disciplinary Journal, Ethiopiac 10(3), https://doi.org/192-206 10.4314/afrrev.v10i3.13

20. Obafemi,N.F \& Ifere, E.O (2015). Monetary policy transmission mechanism in Nigeria: A Comparative Analysis Research in World Economy, 6( 4) https://doi.org/10.5430/rwe.v6n4p93

21. Okwo, I., Eze, F. \& Nwoha, C. 2012). Evaluation of monetary policy outcomes and its effect on price stability in Nigeria, Research Journal of Finance and Accounting, 3(11), 2-12

22. Onakoya, A.B, Ogundajo, G.O \& Johnson, B.S. (2017). Monetary policy and the sustainability of the manufacturing sector in Nigeria, Review of Innovation and Competitiveness, 3(5), 115-221 https://doi.org/10.32728/ric.2018.34/4

23. Onofrei, M., Cărăușu, D. N., \& Lupu, D. (2019). The role of the macroeconomic environment in shaping capital market co-movement in CEE countries. Economic research-Ekonomska istraživanja, 32(1), 3813-3834. https://doi.org/10.1080/1331677X.2019.1675525

24. Onouorah, C.A., Shaib, I.A \& Oyathelemi, E. (2011). The impact of monetary policy on microeconomy and private investment in Nigeria, Research Journal of Finance and Accounting, 2(6), 4-17

25. Oseni, I.O \& Onakoya, A.B (2016). Empirical analysis of fiscal policy shocks and current account dynamics in Nigeria, An International Multidisciplinary Journal, Ethiopia, 7 (1), 28. https://doi.org/10.4314/afrrev.v7i1.15

26. Paligorova, T. \& Santos, J.A.C (2015) Monetary policy and bank risk-taking: Evidence from the corporate loan market, Bis Working Papers, No 580 https://doi.org/10.1016/j.jfi.2016.11.003

27. Ridhwana, M.R , Henri L.F, Groota, B, Nijkampa, P,. \& Rietvelda, P. (2014). The impact of monetary policy on economic activity evidence from a meta-analysis, Tinbergen Institute Discussion Paper

28. Udude, C.C (2014). Monetary policy and economic growth of Nigeria (1981-2012), Journal of Policy and Development Studies, 9(11), 1-15

29. Usman, O.A \& Adejare, A.T. (2014). Impact of monetary policy on industrial growth in Nigeria, International Journal of Academic Research in Business and Social Sciences, 4(1) http://dx.doi.org/10.6007/IJARBSS/v4-i1/507

30. Uwakaeme O.S. (2015). Economic growth in Nigeria: An empirical investigation of determinants and causal relationship (1980-2012), American Journal of Economics, 5(1): 9-20

This article is an open access article distributed under the terms and conditions of the Creative Commons Attribution - Non Commercial - No Derivatives 4.0 International License. 